\title{
MENINGKATKAN AKTIVITAS DAN HASIL BELAJAR SISWA SMAN 1 SUNGAI AMBAWANG MELALUI PEMBELAJARAN MODEL ADVANCE ORGANIZER BERLATAR NUMBERED HEADS TOGETHER (NHT) PADA MATERI KELARUTAN DAN HASIL KALI KELARUTAN
}

\section{Oleh}

\section{H. A. Melati ${ }^{1}$}

\begin{abstract}
Abstrak : Metode pembelajaran yang masih berpusat pada guru menyebabkan rendahnya aktivitas dan hasil belajar siswa kelas XI IPA $_{1}$ SMAN 1 Sungai Ambawang pada mata pelajaran kimia. Penelitian ini bertujuan untuk meningkatkan aktivitas dan hasil belajar siswa pada materi kelarutan dan hasil kali kelarutan dengan menggunakan model Advance Organizer berlatar Numbered Heads Together (NHT). Penelitian ini merupakan penelitian tindakan kelas. Sebanyak 25 orang siswa berpartisipasi dalam penelitian yang dilakukan sebanyak dua siklus. Metode penilitian yang digunakan adalah metode kuantitatif dengan bentuk pendekatan deskriptif menggunakan teknik persentase untuk melihat peningkatan aktivitas dan hasil belajar dari siklus satu sampai siklus dua. Lembar observasi dan tes hasil belajar digunakan untuk melihat aktivitas dan hasil belajar siswa. Hasil penelitian menunjukkan adanya peningkatan terhadap aktivitas yang meliputi visual activities, oral activities, writing activities, mental activities dan hasil belajar siswa yang telah mencapai indikator keberhasilan pada siklus dua.
\end{abstract}

Kata kunci: aktivitas belajar, hasil belajar, advance organizer, numbered heads together (nht), kelarutan dan hasil kali kelarutan.

\section{Pendahuluan}

Mata pelajaran kimia merupakan mata pelajaran yang dianggap sulit oleh siswa. Kebanyakan siswa mengalami kesulitan dalam mempelajari konsep kimia dari pada konsep pelajaran yang lain, hal ini disebabkan karena

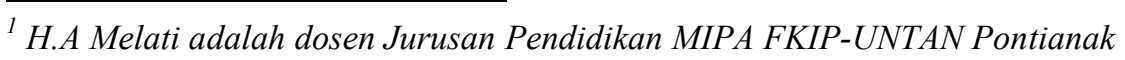


karakteristik ilmu kimia bersifat abstrak (Wiseman, Nakhlek, Kirkwood dan Symington, dalam Rusmansyah 2002). Dalam mempelajari ilmu kimia juga diperlukan pemahaman keterkaitan antar konsep (Solahuddin, 2002). Hasil penelitian yang dilakukan oleh Pendley, Bretz dan Novak, menunjukkan bahwa pada umumnya siswa cenderung belajar dengan menghafal dari pada membangun pemahaman mereka terhadap konsep-konsep kimia tersebut (Rusmansyah, 2003). Siswa tidak bisa mengenali konsep-konsep kunci atau hubungan antar konsep yang diperlukan untuk memahami konsep-konsep tersebut, sehingga siswa tidak dapat membangun konsep-konsep kimia yang fundamental pada awal mereka belajar kimia, hal ini dapat mengakibatkan hasil belajar kimia siswa menjadi rendah.

Pemahaman siswa dalam penguasaan konsep yang rendah berdampak pada rendahnya hasil belajar siswa dan salah satu faktor yang mempengaruhinya adalah metode yang digunakan guru dalam mengajar. Penguasaan konsep yang kurang juga dapat menyebabkan siswa tidak dapat terlibat secara aktif dalam membangun pengetahuan, sikap dan perilaku (Yanti, 2008). Penggunaan metode ceramah yang sering dilakukan oleh guru menjadikan proses pembelajaran terpusat pada guru yang menyebabkan kurangnya interaksi guru dengan siswa maupun siswa dengan siswa.

Salah satu materi dalam mata pelajaran kimia yang dianggap sulit oleh siswa adalah kelarutan dan hasil kali kelarutan. Fakta ini tergambar dari persentase ketuntasan belajar siswa berdasarkan observasi yang dilakukan di kelas XI IPA SMAN 1 Sungai Ambawang tahun ajaran 2009/2010 yang tersaji pada Tabel 1.

Tabel 1. Persentase Ketuntasan Belajar Siswa pada Materi Kelarutan dan Hasil Kali

Kelarutan.

\begin{tabular}{ccccc}
\hline \multirow{2}{*}{ Kelas } & \multicolumn{2}{c}{ Jumlah Siswa } & \multicolumn{2}{c}{ Persentase ( \% ) } \\
\cline { 2 - 5 } XI IPA 1 & Tuntas & Tidak Tuntas & Tuntas & Tidak Tuntas \\
XI IPA 2 & 10 & 13 & 43,48 & 56,52 \\
& 10 & 12 & 45,45 & 54,55 \\
& Rata-rata & & 44,46 & 55,53 \\
\hline
\end{tabular}


Dari Tabel 1 diperoleh informasi bahwa lebih dari 50\% siswa kelas XI IPA belum mencapai ketuntasan hasil belajar dengan Kriteria Ketuntasan Minimal (KKM) sebesar 62. Materi kelarutan dan hasil kali kelarutan dapat dipahami siswa dengan syarat siswa harus mampu mengkaitkan konsep yang mendasarinya dengan konsep yang akan dipelajari. Berdasarkan informasi dari guru, penyebab ketidaktuntasan tersebut dikarenakan siswa belum menguasai konsep prasyarat, seperti konsep mol, reaksi ionisasi, kesetimbangan kimia, $\mathrm{pH}$ larutan asam dan basa, dan seringkali siswa tidak bisa mengkaitkan konsep-konsep tersebut. Hasil wawancara delapan siswa kelas XII IPA dengan tingkat kemampuan akademik berbeda menyatakan sulitnya materi kelarutan dan hasil kali kelarutan karena banyaknya konsep yang harus dipahami serta sulitnya dalam menghubungkan konsep.

Guru sebagai fasilitator dituntut untuk dapat menciptakan pembelajaran yang dapat membuat siswa mengingat konsep-konsep materi yang telah dipelajari dan menghubungkannya dengan konsep yang akan dipelajari. Diskusi lebih lanjut dengan guru bidang studi, terungkap bahwa guru juga menggunakan metode praktikum dan diskusi kelompok dalam pembelajaran di kelas, namun pembelajaran yang dilakukan belum optimal dan masih berpusat pada guru karena ada beberapa tahapan dalam pembelajaran yang tidak dilakukan.

Hasil wawancara dengan guru dan observasi terhadap pembelajaran diperoleh informasi bahwa aktivitas siswa kelas XI IPA 1 lebih rendah dibanding siswa kelas XI IPA 2 . Hasil observasi yang diamati selama proses pembelajaran berlangsung menunjukkan aktivitas siswa yang rendah yaitu visual activities $24 \%$, oral activities $28 \%$, writing activities $28 \%$ dan mental activities $8 \%$. Guru menyadari kekurangan dalam proses pembelajaran seperti kurang dapat mengaktifkan siswa dan membuat suasana kelas menjadi tenang, selain itu guru juga lupa untuk mengingatkan siswa tentang konsep dasar materi sebelumnya. Oleh karena itu, untuk proses pembelajaran selanjutnya, guru menginginkan suatu model pembelajaran yang dapat memperbaiki cara mengajar, khususnya dalam mengaitkan hubungan antara konsep yang telah dipelajari dengan konsep yang akan dipelajari.

Strategi pembelajaran yang tepat dalam menyampaikan materi pelajaran oleh seorang guru akan mendukung tercapainya tujuan pembelajaran. Menurut Abbas, Daud dan Bukoting (2006) menyatakan bahwa guru sebagai salah satu pemeran utama dalam pembelajaran haruslah 
profesional dalam bidangnya agar dapat menjalankan tugas dan fungsinya sebagai pendidik sekaligus sebagai pengajar yang berkompeten. Guru harus menguasai bahan yang diajarkan, terampil mengajarkannya, dan mampu mengatasi berbagai kendala yang ditemui dalam pembelajaran agar tujuan yang telah ditetapkan dapat tercapai secara optimal. Suyadi (2010) menyatakan bahwa guru juga harus peka terhadap persoalan-persoalan yang muncul dalam proses pembelajaran. Bahkan guru dituntut untuk lebih peka terhadap prestasi belajar siswa-siswanya. Kepekaan dan sensitivitas inilah yang akan mendorong naluri guru untuk memperbaiki proses pembelajaran.

Hasil diskusi antara peneliti dengan guru, disepakati untuk melakukan perubahan model pembelajaran dari metode ceramah ke model Advance Organizer dalam pembelajaran kimia. Menurut Saftory (2010) melalui Advance Organizer siswa memperoleh pengetahuan baru yang dikaitkan dengan pengetahuan yang telah ada pada pembelajaran. David Ausubel (dalam Dahar, 1998) memperkenalkan konsep Advance Organizer dalam teorinya. Advance organizer mengarahkan para siswa pada informasi/materi yang akan mereka pelajari dan menolong mereka untuk mengingat kembali informasi yang berhubungan dalam membantu menanamkan pengetahuan baru. Dalam proses belajar mengajar apa yang telah diketahui siswa berupa materi pelajaran yang telah dipelajarinya siswa dapat dimanfaatkan dan dijadikan sebagai titik tolak dalam mengkomunikasikan informasi atau ide baru dalam kegiatan antara materi pelajaran yang telah dipelajari dengan informasi atau ide baru. Hasil penelitian yang dilakukan oleh Fadhilah (2010), memberikan pengaruh terhadap peningkatan hasil belajar siswa kelas XI IPA SMA Negeri 1 Sungai Ambawang pada materi larutan penyangga sebesar 27,94\% melalui pembelajaran model Advance Organizer tipe comparative. Penelitian serupa yang dilakukan oleh Ratnaningsih (2009) memberikan peningkatan terhadap aktivitas dan hasil belajar pada pembelajaran menggunakan model Advance Organizer dengan metode eksperimen.

Pelibatan seluruh siswa untuk dapat aktif dalam proses pembelajaran sangat diperlukan. Dalam kelompok kooperatif, pembelajaran menjadi sebuah aktivitas yang bisa membuat para siswa lebih unggul diantara temanteman sebayanya (Slavin, 2008). Beberapa kajian yang dilakukan oleh Deutsch dan Thomas telah menunjukkan bahwa ketika para siswa bekerja bersama-sama untuk meraih sebuah tujuan kelompok, membuat mereka 
mengekspresikan norma-norma yang baik dalam melakukan apa pun yang diperlukan untuk keberhasilan kelompok (Slavin, 2008).

Pembelajaran kooperatif tipe NHT dapat memotivasi setiap siswa menjadi siap semua, dapat melakukan diskusi dengan sungguh-sungguh, dan siswa yang pandai dapat mengajari siswa yang kurang pandai (Ibrahim, 2000). Pembelajaran melalui pendekatan tipe ini banyak persamaan dengan pendekatan yang lain, namun pendekatan ini memberi penekanan pada penggunaan struktur tertentu yang dirancang untuk mempengaruhi pola interaksi siswa. Pembelajaran kooperatif tipe $N H T$, menuntut semua siswa untuk aktif dalam kegiatan belajar mengajar sehingga dalam pelaksanaannya tidak hanya siswa yang pintar saja yang aktif, tetapi siswa yang pasif akan termotivasi untuk ikut aktif. Penelitian tentang penggunaan model pembelajaran kooperatif tipe $N H T$ telah berhasil meningkatkan minat belajar, dan aktivitas belajar siswa pada mata pelajaran kimia (Yumiasih, 2009; Himanasari, 2009; Apsari 2010).

Aktivitas dan hasil belajar yang rendah mendasari dilakukannya penelitian tindakan kelas (PTK) untuk memperbaiki proses pembelajaran yang diharapkan dapat meningkatkan aktivitas dan hasil belajar siswa kelas XI IPA SMA Negeri 1 Sungai Ambawang pada materi kelarutan dan hasil kali kelarutan dengan menggunakan Advance Organizer berlatar Numbered Heads Together (NHT).

\section{Metode Penelitian}

1. Bentuk penelitian adalah penelitian tindakan kelas (PTK)

2. Desain Penelitian meliputi :

a. Tempat penelitian adalah SMAN 1 Sungai Ambawang

b. Penelitian dilaksanakan pada akhir tahun ajaran 2010/2011, yakni bulan Mei. Penentuan waktu penelitian mengacu pada kalender akademik sekolah.

c. Jumlah siklus yang dilaksanakan dalam penelitian ini sangat bergantung pada keberhasilan setiap siklus. Materi pada setiap siklus adalah:

Siklus I : Pembelajaran Advance Organizer berlatar NHT pada materi kelarutan dan hasil kali kelarutan sub pokok bahasan Pengertian kelarutan dan hasil kali kelarutan serta meramalkan pengendapan. 
Siklus II : Pembelajaran Advance Organizer berlatar NHT pada materi kelarutan dan hasil kali kelarutan sub pokok bahasan pengaruh ion senama dan $\mathrm{pH}$ terhadap kelarutan.

3. Subjek dalam penelitian ini adalah 25 orang siswa kelas XI IPA 1 semester genap tahun pelajaran 2010/2011.

4. Instrumen yang digunakan dalam penelitian ini adalah:

a. Lembar Observasi tertutup yang terdiri atas lembar observasi guru dalam melaksanakan RPP dan lembar observasi aktivitas siswa.

b. Lembar Observasi Terbuka

c. Tes Hasil Belajar

5. Data yang dikumpulkan dalam penelitian ini adalah:

a. Jawaban siswa pada hasil pengerjaan soal diskusi dan soal test.

b. Hasil pengamatan terhadap kegiatan pembelajaran dan aktivitas siswa.

c. Catatan lapangan yang memuat catatan kejadian-kejadian selama berlangsungnya proses pembelajaran

6. Prosedur Penelitian

Metode penelitian yang digunakan adalah metode kuantitatif dengan bentuk pendekatan deskriptif menggunakan teknik persentase untuk melihat peningkatan yang terjadi dari siklus ke siklus yang dilakukan dirinci dari perencanaan, pelaksanaan tindakan, pengamatan dan refleksi-evaluasi. (1) perencanaan : Merancang skenario pembelajaran yang berisikan langkahlangkah proses pembelajaran menggunakan model Advance Organizer Berlatar NHT, Merancang soal diskusi pada setiap siklus, merancang lembar observasi aktivitas siswa selama mengikuti proses belajar mengajar, merancang lembar observasi untuk melihat kegiatan belajar mengajar di kelas, mendiskusikan catatan lapangan selama proses pembelajaran berlangsung, menyusun soal tes yang berupa tes tertulis untuk mengetahui peningkatan hasil belajar siswa pada siklus satu dan siklus selanjutnya, membagi siswa dalam beberapa kelompok yang heterogen satu minggu sebelum pelaksanaan tindakan, dan mencoba menggunakan model pembelajaran Advance Organizer Berlatar NHT di kelas yang tidak dikenai tindakan; (2) Pelaksanaan Tindakan : Guru melaksanakan tindakan sesuai dengan skenario yang telah dirancang sedangkan peneliti sebagai observer; (3) Observasi pada penelitian ini dilakukan terhadap aktivitas siswa dalam proses belajar mengajar oleh peneliti dan lima observer; (4) Refleksi 
dilakukan oleh pengajar dan peneliti dengan berdiskusi tentang hasil yang didapat pada siklus tersebut dan memutuskan apakah siklus dilanjutkan atau tidak. Jika siklus dilanjutkan maka akan disusun kembali perencanaan untuk tindakan pada siklus selanjutnya. Kegiatan pembelajaran pada siklus dua dipengaruhi oleh hasil kegiatan pada siklus satu. Aktivitas yang diamati meliputi visual activities yaitu memperhatikan pada saat guru menyampaikan materi; oral activities yaitu bertanya kepada guru mengenai materi yang tidak dipahami, bertanya kepada teman sekelompok mengenai materi yang belum jelas pada saat diskusi, mengeluarkan pendapat pada saat diskusi kelompok; writing activities yaitu mengerjakan soal yang diberikan guru; mental activities yaitu menanggapi presentasi teman. Setiap siklus selalu diakhiri dengan pemberian soal tes. tes dilakukan untuk mengetahui kemampuan siswa secara individu dalam memahami materi yang dipelajari.

7. Indikator Keberhasilan

Untuk mengukur keberhasilan pembelajaran pada penelitian ini diperlukan indikator. Indikator aktivitas dan hasil belajar yang diamati dapat dilihat pada Tabel 2. Penetapan indikator aktivitas pada setiap aspek pada Tabel 2 didasarkan pada hasil observasi dan diskusi dengan guru. Pada saat sebelum dilakukan tindakan, persentase awal visual activities siswa adalah $24 \%$, oral activities adalah $28 \%$, writing activities $28 \%$ dan mental activities $8 \%$.

Tabel 2. Indikator Keberhasilan

\begin{tabular}{ll}
\hline Aktivitas & $\geq 48 \%$ siswa aktif dalam visual activities. \\
& $\geq 56 \%$ siswa aktif dalam oral activities. \\
& $\geq 60 \%$ siswa aktif dalam writing activities. \\
& $\geq 20 \%$ siswa aktif dalam mental activities \\
\hline Hasil & $\geq 60 \%$ siswa mencapai ketuntasan belajar (KKM $=67)$ dengan \\
belajar & menggunakan model Advance Organizer berlatar NHT pada \\
& materi kelarutan dan hasil kelarutan.
\end{tabular}

\section{Hasil dan Pembahasan}

Penelitian ini dilakukan pada siswa kelas XI IPA 1 SMAN 1 Sungai Ambawang yang berjumlah 25 siswa. Tindakan yang dilakukan terdiri dari dua siklus, tiap siklusnya terdiri dari tahap-tahap perencanaan, tindakan, observasi dan refleksi. Satu siklus terdiri dari satu kali pertemuan dengan alokasi waktu 2 x 45 menit dengan menggunakan satu rencana pelaksanaan 
pembelajaran yang telah disiapkan dan materi yang dibahas sesuai dengan rencana pelaksanaan pembelajaran.

Peneliti dan guru berkolaborasi membuat rencana pembelajaran dengan menyusun skenario tindakan menggunakan model Advance Organizer berlatar NHT. Perkembangan kegiatan belajar mengajar dan peningkatan aktivitas siswa yang dapat berdampak positif terhadap hasil belajar siswa selama dilaksanakan tindakan (selama dua siklus) melalui model Advance Organizer berlatar NHT dijabarkan dalam pembahasan.

Aktivitas belajar siswa terhadap pembelajaran dengan model Advance Organizer berlatar NHT diukur menggunakan lembar observasi. Adapun aktivitas siswa yang dilakukan pada siklus satu yaitu Visual Activities dilakukan oleh 22 siswa (88 \%); Oral Activities 49,33\% yang meliputi bertanya kepada guru dilakukan oleh lima siswa (20\%), bertanya kepada teman dilakukan oleh 20 siswa (80\%), mengeluarkan pendapat dilakukan oleh 12 siswa (48\%); Writing Activities dilakukan oleh 23 siswa (92\%); dan Mental Activities dilakukan oleh dua siswa (8\%). Empat ktivitas yang diamati menunjukkan bahwa masih ada dua aktivitas yang tidak mencapai indikator keberhasilan yaitu oral activities dan mental activities, untuk mengatasi masalah pada siklus dua guru akan meningkatkan perannya sebagai mediator dalam mengatur jalannya proses evaluasi.

Hasil belajar siswa setelah dilakukan tindakan siklus satu sudah mencapai indikator keberhasilan ( $\geq 60 \%$ siswa tuntas). Siswa yang mengalami ketuntasan belajar (memperoleh nilai $\geq 67$ ) pada siklus satu sebanyak 17 siswa dari 25 siswa yang mengikuti tes. Siswa yang tidak tuntas (delapan siswa) masih keliru dalam menghitung kelarutan suatu ion. Oleh karena itu, pada siklus dua guru akan mengulas secara singkat tentang materi pengertian kelarutan dan hasil kali kelarutan serta meramalkan pengendapan. Persentase ketuntasan siswa pada siklus satu adalah $68 \%$. Ketidaktuntasan siswa terutama dikarenakan ketidakdisiplinan serta aktivitas yang kurang didalam proses pembelajaran. Hasil tindakan pada siklus satu menunjukkan bahwa siklus dua harus dilakukan karena proses pembelajaran belum maksimal dan masih terdapat dua aktivitas dari empat aktivitas yang belum mencapai indikator keberhasilan, meskipun hasil belajar siswa pada evaluasi siklus satu telah mencapai indikator keberhasilan.

Pengamatan oleh observer yang tercatat pada lembar observasi aktivitas siswa dilakukan per lima menit. Aktivitas siswa yang dilakukan 
pada siklus dua menunjukkan bahwa telah terjadi peningkatan aktivitas yang meliputi Visual Activities dilakukan oleh 25 siswa (100\%); Oral Activities yaitu $78,67 \%$ yang meliputi bertanya kepada guru dilakukan oleh 14 siswa (56\%), bertanya kepada teman dilakukan oleh 25 siswa (100\%), mengeluarkan pendapat dilakukan oleh 20 siswa (80\%); Writing Activities dilakukan oleh 24 siswa (96\%); dan Mental Activities dilakukan oleh 6 siswa (24 \%). Peningkatan aktivitas dapat diketahui dari semakin banyaknya jumlah siswa yang aktif dalam proses pembelajaran. Peningkatan aktivitas belajar siswa mulai dari prasiklus sampai dengan siklus dua yang meliputi Visual Activities, Oral Activities, Writing Activities, dan Mental Activitiesdisajikan pada Gambar 1.

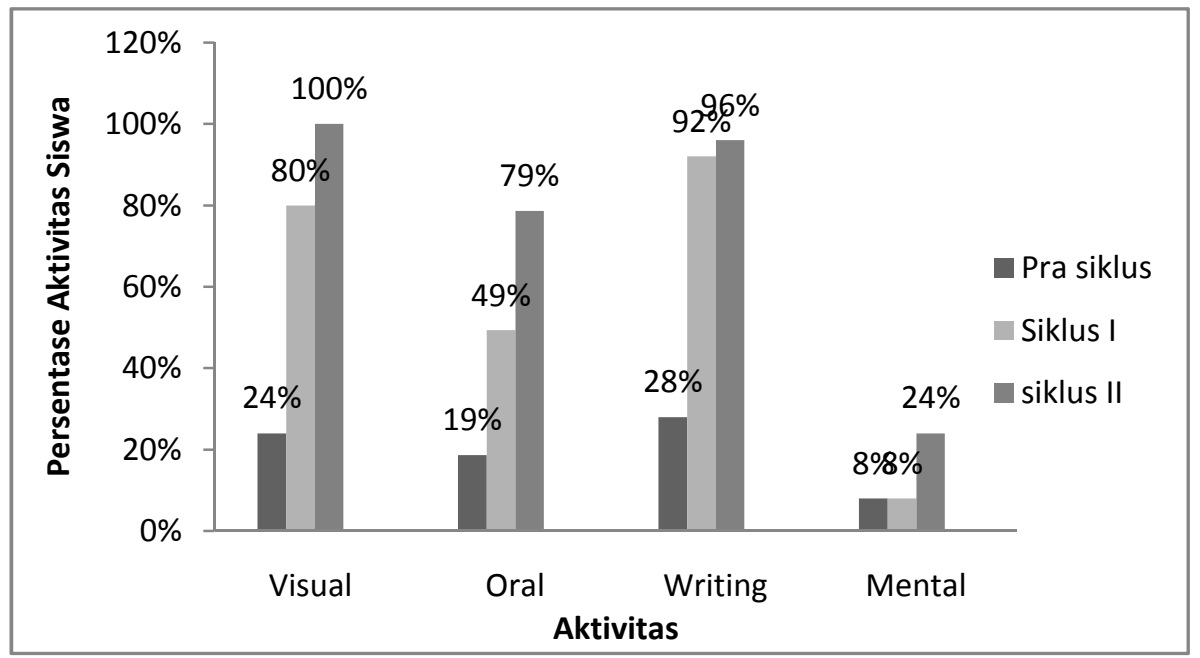

Gambar 1. Persentase Peningkatan Aktivitas Siswa

Tes hasil belajar siklus dua menunjukkan perkembangan hasil belajar yang diperoleh siswa setelah dilakukan tindakan. Siswa yang mengalami ketuntasan belajar atau yang memperoleh nilai $\geq 67$ pada siklus dua sebanyak 22 siswa dari jumlah siswa seluruhnya yang mengikuti evaluasi (25 siswa) dengan persentase $88 \%$. Hasil refleksi pada siklus dua diketahui bahwa proses belajar mengajar sudah terlaksana dengan baik, aktivitas siswa serta hasil belajar siswa telah mencapai indikator yang diinginkan. Perkembangan peningkatan ketuntasan belajar siswa pada penelitian tindakan kelas ini dapat dilihat pada Gambar 2. 


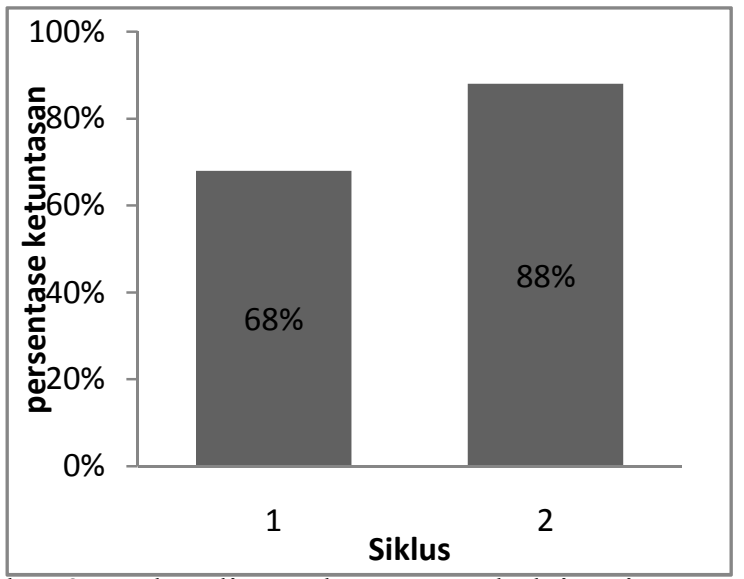

Gambar 2. Perbandingan ketuntasan belajar siswa pada siklus satu dan dua

\section{Kesimpulan}

Hasil pengamatan terhadap aktivitas dan hasil belajar siswa pada siklus satu dan dua telah mencapai indikator keberhasilan, sehingga dapat diambil kesimpulan bahwa penerapan model Advance Organizer berlatar NHT dapat meningkatkan aktivitas dan hasil belajar siswa kelas XI IPA SMAN 1 Sungai Ambawang.

\section{Saran}

Pembelajaran melalui model Advance Organizer berlatar Numbered Heads Together (NHT) dapat menjadi salah satu alternatif bagi guru dalam proses belajar mengajar. Perhatian terhadap alokasi waktu diperlukan pada saat melaksanakan model Advance Organizer berlatar Numbered Heads Together (NHT).

\section{Daftar Rujukan}

Abbas, N., Daud, D., dan Bukoting, P. 2006. Meningkatkan Hasil Belajar Matematika Siswa Melalui Model Pembelajaran Berdasarkan Masalah Dengan Penilaian Portofolio di SMPN 10 Kota Gorontalo. (Online)

(http://jurnaljpi.wordpress.com/2008, diakses 12 desember 2010). 
Apsari, N. 2010. Upaya Meningkatkan Aktivitas dan Hasil Belajar Melalui Model Kooperatif Tipe Numbered Heads Together (NHT) Pada Materi Reaksi Redoks Terhadap Siswa Kelas X SMAN 1 Sungai Ambawang. Skripsi. Pontianak: FKIP UNTAN

Dahar, R.W. 1998. Teori-teori Belajar. Jakarta: Depdikbud.

Fadhilah, R. 2010. Pengaruh Pembelajaran Advance Organizer Tipe Comparative Terhadap Hasil Belajar dan Retensi Belajar Siswa Kelas XI IPA SMAN 1 Sungai Ambawang pada Materi Larutan Penyangga. Skripsi. Pontianak: FKIP UNTAN

Himanasari, F. 2009. Meningkatkan Minat dan Hasil Belajar Siswa Kelas X SMA Negeri 1 Sungai Kunyit pada Materi Hidrokarbon. Skripsi. Pontianak: FKIP UNTAN.

Ibrahim, M. 2000. Pembelajaran Kooperatif. Surabaya:Unesa University Press.

Ratnaningsih, L. 2009. Peningkatan Kualitas Pembelajaran Kimia Melalui Model Advance Organizer dengan Metode Eksperimen pada Pokok Bahasan Kelarutan dan Hasil Kali Kelarutan di SMA Negeri 6 Kota Bengkulu. (online)

http://library.unib.ac.id/koleksi/Lenni Ratnaningsih-FKIP-KimJuli2009.pdf diakses 10 januari 2011

Rusmansyah. 2002. Penerapan Metode Latihan Berstruktur Dalam Meningkatkan Pemahaman Siswa Terhadap Konsep Persamaan Reaksi Kimia. Jurnal Pendidikan Nasional dan Kebudayaan no. 035-Mei 2002. Jakarta: Departemen Pendidikan Nasional dan Kebudayaan

. 2003. Meningkatkan Pemahaman Siswa Terhadap Konsep Kimia Karbon Melalui Strategi Peta Konsep (Concept Mapping). Jurnal Pendidikan Nasional dan Kebudayaan no. 040-Mei 2003. Jakarta: Departemen Pendidikan Nasional dan Kebudayaan.

Saftory, N. 2010. Makalah Model Pembelajaran. (online)

(http://kumpulantugas-nurkhanah.blogspot.com/2010/12/makalahmodel-pembelajaran.html/, diakses 19 Desember 2010).

Slavin, R. 2008. Cooperatif Learning. Bandung: Nusa Media. 
Solahuddin, A. 2002. Iplementasi Teori Ausabel Pada Pembelajaran Senyawa Karbon Di SMU. Jurnal Pendidikan Nasional dan Kebudayaan no. 036-Mei 2002. Jakarta: Departemen Pendidikan Nasional dan Kebudayaan.

Suyadi. 2010. Panduan Penelitian Tindakan Kelas. Yogjakarta: DIVA Press.

Yanti, D.P. 2008. Teacher Centered. (online) (http://bintang bangsaku.com/artikel/teacher-centered. diakses tanggal 5 April 2011)

Yumiasih. 2009. Peningkatkan hasil belajar siswa kelas X SMA Negeri 1 Rasau Jaya pada materi reaksi redoks. Skripsi. Pontianak: FKIP UNTAN. 